\title{
Classroom Management: A Challenging Part in Beginning English Teachers' Career Entry Stage
}

\author{
Adnan Tahir ${ }^{1}$, Akhtar Iqbal ${ }^{1} \&$ Abrar Hussain Qureshi $^{2}$ \\ ${ }^{1}$ RIPHAH International University, Faisalabad, Pakistan \\ ${ }^{2}$ University of Lahore, Pakpattan, Pakistan \\ Correspondence: Adnan Tahir, RIPHAH International University, Faisalabad, Pakistan. E-mail: \\ adnantahirqureshi@gmail.com
}

Received: January 17, 2018 Accepted: March 8, 2018 Online Published: March 22, 2018

doi:10.5539/ijel.v8n4p155

URL: https://doi.org/10.5539/ijel.v8n4p155

\begin{abstract}
Classroom management is the vital professional content of successful professionalization of beginning teachers. This study explores the challenges beginning English teacher face in classroom management during early years of teaching career. Through survey method and using a valid questionnaire tool the required data was collected and then analyzed statistically using SPSS 16. A sample of beginning English teachers was carefully chosen through stratified sampling from 43 schools located in Faisalabad city, Pakistan. In total, 113 participants responded to questionnaires and 20 participated in the interviews. It was found that a large number of students in classes, variation in cognitive approach and mother tongue, adaptation to new teaching and learning techniques, and ineptness in using latest ICT based audio-visual aids are main challenges in classroom management that affect the ultimate performance of beginning English teachers. These issues require more attention to improve teachers' performance. It is hoped that findings of this study would help beginning teachers and educationists in developing strategies to cope with classroom management challenges in the perspective professional socialization.
\end{abstract}

Keywords: classroom management, professionalism, beginning teachers, performance

\section{Introduction}

\subsection{Background}

English language has acquired the status of global language for the last few decades and its importance in every discipline of life cannot be denied (Crystal, 1997). In Pakistan, English has taken over another important role while being second language of the country. In Pakistan, the area of English Language Teaching is passing through different rapid reforms both in public sector and in the private sector (Akhtar \& Kausar, 2011). This study views the professional socialization of English teachers in Pakistan in view of present ELT reforms. It has been observed with grave concern that English teaching community in Pakistan needs much more to do to meet international standards of English language teaching (Tahir \& Qadir, 2012). There are a number of causes and facts of this concern ranging from pedagogical to administrative dimensions. Scores of problems fall under the category of professional socialization of English teachers in which teachers being the part of an academic institution face different problems.

\subsection{Classroom Management: Teacher Socialization Content}

In the perspective of teacher socialization and especially for their professional learning while serving in an organization, managing a classroom is an important professional task to be done. Pollard (1982) divides organizational contexts into two main categories i.e., influence of pupils on their teacher and persuasions on teacher-student interaction in the form of classroom ecology. Many other studies (e.g., Baumrind, 1980; Blase, 1986; Doyle, 1979; Riseborough, 1988) have confirmed the same findings related to the influence of classroom ecology and pupil-teacher relationship. Doyle (1979) has asserted that the selection of appropriate teaching methodologies is directly influenced by the students' classroom behavior and class participation. This process of interactive socialization affect the performance of both teacher and students. The one significant element which makes a teacher better in skills, knowledge and experience in interactive socialization is students' role (Larson, 1986). 
Different scholars like Denscombe (1982), and Connell (1985) enlighten the facts about the classroom related to the teacher's physical condition while delivering lecture(s). They have discussed different factors about teaching as a profession e.g., size of the classroom and strength of the students, access to quality material and resources, and feasibility of time. An ideal teacher is considered as the one who switches and adopts the suitable strategy keeping the environment and settings of a classroom in view (Doyle, 1977).

\subsection{Challenges to Classroom Management in Pakistan}

English teachers in Pakistan face the biggest issue of large classes which create the strong uncomforted feelings in teachers for classroom management (Sarwar, 2001). In Pakistani government run schools, English teachers feel frustrated to perform in the class of more than 80 students (ibid). According to Jumani (2007) and Sarwar (2001), the beginning teachers have to deal with a number of different problems related to classroom management in these large classes. These problem include nervousness and anxiety, disciplinary issues of students, unsuccessful implementation of syllabus, ineptness in manipulating modern audio-visual aids and outdated teaching methods. Such factor cast a negative impact on beginning teachers' professional socialization and their self-professional image (ibid). The stereotypical system of language testing and evaluation discourage beginning teachers to adopt any new teaching techniques (Coleman, 1989). Therefore, more attention is required towards the beginning teachers in Pakistan to address their professional learning problems.

\subsection{Research Question(s)}

The present study has examined the following research question:

- What challenges do beginning English teachers face related to classroom management in Pakistani schools?

To cover the scope of research question, the study has explored the following areas of classroom management:
i. number of students in a class,
ii. students' classroom behavior,
iii. students' interaction, pupils' response to the teaching,
iv. beginning teachers' adaptation to new teaching techniques,
v. bilingual medium of instruction,
vi. non-availability of study material,
vii. difficulty in motivating students,
viii. expertise in using of audio-visual aids.

These areas were taken with the intention to cover the maximum issues a beginning teacher face in managing a classroom in Pakistani context. The study has also incorporated researchers' recommendations for beginning English teachers to cope with the classroom management challenges.

\section{Method}

The purpose of the study was to identify the challenges of classroom management in Pakistani schools so that they may be resolved. The issue of teacher professional learning in classroom management skills contributes to the overall performance of English teachers and ultimately to the performance of students (Marzano, Marzano, \& Pickering, 2003). Mainly, the objectives of this research and the methods to be used to ascertain the answers of the research questions can be described through research approach.

\subsection{Research Design and Sampling}

In this study, the mixed method approach was used in which qualitative research designed played the main part and quantitative research method techniques were also employed. To develop the questionnaire for data collection, the questions were designed in order to know the personal experience of beginning English teachers regarding classroom management. As Creswell (1994) defines descriptive research method as a useful tool to describe any condition and situation to collect the data, therefore, descriptive method of research was practiced to conduct the study. The population for this study comprised beginning English teachers, presently serving in the schools of Faisalabad having no more than 4 years of teaching experience. A total number of 113 beginning English teachers participated in this study. The selection of participants was based on probability sampling technique. As it was not a homogeneous group, for representing the whole population stratified random sampling technique was applied so as to attain truly representing sample group. The sample comprised the participants from strata including male and female, urban and rural and public and private schools of Faisalabad city, Pakistan. For this exploratory study, the survey research design was the most suitable design for collecting the 
viewpoints of beginning English teachers. To get maximum possible accurate results, cross-sectional survey method was selected for data collection in the same given time from the whole population.

\subsection{Questionnaire as Survey Instrument}

Firstly, the researchers made an appropriate list of challenges related statements/questions in classroom management which were then used to collect data for this research study. No messy situation or arbitrariness was faced during generating these survey questions. These statements/questions mentioned were either generated by the researchers or borrowed and molded from the previous studies conducted for the same purposes (Hudson, 2012; Ingersoll \& Strong, 2011; Rees, 2015; Tahir \& Qadir, 2012). According to certain measures suiting the contents of this study. Every statement/question has used particular suitable diction to develop and produce the actual focus on the concept of the study.

The survey questionnaire, as the main data collection tool, was used for the collection of required data. To know the degree and intensity of the issues related to the classroom management, the questionnaire was developed on Likert scale format in which five options from strongly disagree to strongly agree were given to the respondents to choose one from them. The following scale was used to interpret the offered responses of the statements/questions by the respondents on returning the questionnaire after being filled:
Range
Interpretation
$0.00-1.00$
(SD) Strongly disagree
$1.01-2.00$
(D) Disagree
$2.01-3.00$
(N) Neutral
$3.01-4.00$
(A) Agree
$4.01-5.00$
(SA) Strongly agree

\section{- Piloting the Questionnaire}

After developing the questionnaire, it was presented to 20 respondents so that its validity could be checked; however, the response from the said respondents was not included in the data collected or its analysis. These 20 questionnaires were served to get suggestions from the respondents if they needed any improvement or rectification in statements/questions. It was found very helpful in improving the validity and efficiency of the research instrument selected as questionnaire which was then reviewed and modified as per the valid propositions/recommendations from respondents. For reliability check, Cronbach's alpha was checked which resulted as 0.89 , confirming the questionnaire tool as statistically reliable.

\subsection{Interviewing}

Following the practices of a sound mixed method research, the study did not rely only on the questionnaires which sometimes, being self-completed by the respondents, may be considered superficial (Robson, 2002). The interviews were conducted to confirm the results obtained through questionnaires. Though sometimes, structured interviews were favored for pure exploratory research (Saunders et al., 2007), this study has used semi-structured approach for collecting the required data. These semi-structured interviews prove more flexible and develop more understanding and clarity of the phenomenon being studied (Denzin \& Lincoln, 2000). The study reveals that whilst teachers perceive their task mastery of teaching skill, they represent different kinds of individual and institutional challenges which affect their professional socialization. Having been selected through convenient, volunteer sampling (Cohen et al., 2007), these beginning English teachers were interviewed to confirm the quantitative data collected already through questionnaires. In conformity with the suggestion of Miles \& Huberman (1994), these selected teachers were from the group who had already participated in the questionnaire data collection.

\subsection{Data Collection Procedure}

The researchers visited the institutions and presented the questionnaires to the selected respondents. Finally, the total response rate remained $81 \%$ which was encouraging for the researchers and increased motivational level. Out of 150 questionnaires, 121 were retuned but 08 filled questionnaires were not included for data analysis because of some ambiguous answers. Therefore, finally 113 filled questionnaires were finalized for their analysis so that maximum possible accurate results could be achieved. This process of data collection took almost three months in finding the respondents, introducing this research to them, delivering questionnaires and then getting the filled questionnaires back. Comprising a sequential mixed-methods approach: an initial questionnaire survey distributed to a sample of beginning English teachers $(\mathrm{n}=113)$ and subsequent semi-structured interviews with 
selected teachers from five chosen schools $(n=20)$ were conducted to supplement the results obtained through questionnaires.

\section{Results}

\subsection{Questionnaire}

The data was analyzed descriptively using the popular statistical software, SPSS-16 and the statistics of each item were calculated separately. The data was entered precisely and carefully and a detailed exploratory data analysis (EDA) was conducted beforehand. The data was found normal and suitable for further analysis. The frequency, cumulative percentage, means, mode, median, standard deviation and other necessary descriptive statistics were utilized to get appropriate results of the analysis.

Table 1. Frequency of response from the respondents for questions/statements related to classroom management

\begin{tabular}{|c|c|c|c|c|}
\hline Domain/Item & Response & Frequency & Percent & Cumulative Percent \\
\hline \multirow[t]{2}{*}{ Class size } & SD & 12 & 10.6 & 10.6 \\
\hline & $\mathrm{D}$ & 31 & 27.4 & 38.1 \\
\hline \multirow{4}{*}{$\begin{array}{l}\text { It is difficult to manage a class of large number of students } \\
\text { like more than } 30 \text { students in one class. }\end{array}$} & $\mathrm{N}$ & 26 & 23.0 & 61.1 \\
\hline & $\mathrm{A}$ & 29 & 25.7 & 86.7 \\
\hline & SA & 15 & 13.3 & 100.0 \\
\hline & Total & 113 & 100.0 & \\
\hline \multirow[t]{2}{*}{ Student Behavior } & $\mathrm{SD}$ & 4 & 3.5 & 3.5 \\
\hline & $\mathrm{D}$ & 28 & 24.8 & 28.3 \\
\hline \multirow{4}{*}{$\begin{array}{l}\text { Behavioral problems of students such as lack of attention, } \\
\text { lack of motivation and less participation create become } \\
\text { problematic in managing the class discipline. }\end{array}$} & $\mathrm{N}$ & 21 & 18.6 & 46.9 \\
\hline & $\mathrm{A}$ & 48 & 42.5 & 89.4 \\
\hline & SA & 12 & 10.6 & 100.0 \\
\hline & Total & 113 & 100.0 & \\
\hline \multirow[t]{2}{*}{ Rowdy students } & $\mathrm{SD}$ & 7 & 6.2 & 6.2 \\
\hline & $\mathrm{D}$ & 15 & 13.3 & 19.5 \\
\hline \multirow{4}{*}{$\begin{array}{l}\text { You feel it difficult to handle rowdy (noisy) students } \\
\text { creating disturbance in the class. }\end{array}$} & $\mathrm{N}$ & 27 & 23.9 & 43.4 \\
\hline & A & 38 & 33.6 & 77.0 \\
\hline & SA & 26 & 23.0 & 100.0 \\
\hline & Total & 113 & 100.0 & \\
\hline \multirow[t]{2}{*}{ Individual attention } & SD & 6 & 5.3 & 5.3 \\
\hline & $\mathrm{D}$ & 12 & 10.6 & 15.9 \\
\hline \multirow{4}{*}{$\begin{array}{l}\text { Some students involve you more in their interaction and } \\
\text { thus other students feel ignored. }\end{array}$} & $\mathrm{N}$ & 28 & 24.8 & 40.7 \\
\hline & $\mathrm{A}$ & 57 & 50.4 & 91.2 \\
\hline & SA & 10 & 8.8 & 100.0 \\
\hline & Total & 113 & 100.0 & \\
\hline \multirow[t]{2}{*}{ Discipline maintenance } & SD & 12 & 10.6 & 10.6 \\
\hline & $\mathrm{D}$ & 28 & 24.8 & 35.4 \\
\hline \multirow{4}{*}{$\begin{array}{l}\text { Being a new teacher, you feel it a bit difficult to maintain } \\
\text { the discipline of the senior level classes, i.e., } 9^{\text {th }} \& 10^{\text {th }} \\
\text { grades. }\end{array}$} & $\mathrm{N}$ & 21 & 18.6 & 54.0 \\
\hline & A & 39 & 34.5 & 88.5 \\
\hline & SA & 13 & 11.5 & 100.0 \\
\hline & Total & 113 & 100.0 & \\
\hline \multirow[t]{2}{*}{ Student Feedback } & SD & 6 & 5.3 & 5.3 \\
\hline & $\mathrm{D}$ & 13 & 11.5 & 16.8 \\
\hline \multirow{4}{*}{$\begin{array}{l}\text { You are satisfied with the rate of response and attention the } \\
\text { students give to your lessons. }\end{array}$} & $\mathrm{N}$ & 31 & 27.4 & 44.2 \\
\hline & A & 47 & 41.6 & 85.8 \\
\hline & SA & 16 & 14.2 & 100.0 \\
\hline & Total & 113 & 100.0 & \\
\hline \multirow[t]{2}{*}{ New Teaching Techniques } & SD & 13 & 11.5 & 11.5 \\
\hline & $\mathrm{D}$ & 43 & 38.1 & 49.6 \\
\hline \multirow{4}{*}{$\begin{array}{l}\text { Your students actively participate in any innovative ideas } \\
\text { and techniques you use in class. }\end{array}$} & $\mathrm{N}$ & 12 & 10.6 & 60.2 \\
\hline & A & 29 & 25.7 & 85.8 \\
\hline & SA & 16 & 14.2 & 100.0 \\
\hline & Total & 113 & 100.0 & \\
\hline \multirow[t]{2}{*}{ Non-Native Language } & SD & 9 & 8.0 & 8.0 \\
\hline & $\mathrm{D}$ & 15 & 13.3 & 21.2 \\
\hline \multirow{4}{*}{$\begin{array}{l}\text { Your students feel problematic when you don't use the } \\
\text { native language and speak only English during your } \\
\text { lessons. }\end{array}$} & $\mathrm{N}$ & 22 & 19.5 & 40.7 \\
\hline & A & 46 & 40.7 & 81.4 \\
\hline & SA & 21 & 18.6 & 100.0 \\
\hline & Total & 113 & 100.0 & \\
\hline
\end{tabular}




\begin{tabular}{|c|c|c|c|c|}
\hline \multirow[t]{2}{*}{ Effective Study Material } & SD & 7 & 6.2 & 6.2 \\
\hline & $\mathrm{D}$ & 24 & 21.2 & 27.4 \\
\hline \multirow{4}{*}{$\begin{array}{l}\text { Your students successfully use the study material other than } \\
\text { the textbooks you provide them for extra study. }\end{array}$} & $\mathrm{N}$ & 21 & 18.6 & 46.0 \\
\hline & A & 50 & 44.2 & 90.3 \\
\hline & SA & 11 & 9.7 & 100.0 \\
\hline & Total & 113 & 100.0 & \\
\hline \multirow[t]{2}{*}{ Assignment Submission } & SD & 3 & 2.7 & 2.7 \\
\hline & D & 13 & 11.5 & 14.2 \\
\hline \multirow{4}{*}{$\begin{array}{l}\text { It is very rare to find students making effort by themselves } \\
\text { to submit their assignment on time. }\end{array}$} & $\mathrm{N}$ & 17 & 15.0 & 29.2 \\
\hline & A & 54 & 47.8 & 77.0 \\
\hline & SA & 26 & 23.0 & 100.0 \\
\hline & Total & 113 & 100.0 & \\
\hline \multirow[t]{2}{*}{ Motivating students } & SD & 4 & 3.5 & 3.5 \\
\hline & D & 7 & 6.2 & 9.7 \\
\hline \multirow{4}{*}{$\begin{array}{l}\text { Motivating all the students of the class with one technique } \\
\text { doesn't suit due to differences in their mental abilities and } \\
\text { personal interests. }\end{array}$} & $\mathrm{N}$ & 10 & 8.8 & 18.6 \\
\hline & A & 67 & 59.3 & 77.9 \\
\hline & SA & 25 & 22.1 & 100.0 \\
\hline & Total & 113 & 100.0 & \\
\hline \multirow[t]{2}{*}{ Audio-Visual Aids } & SD & 1 & .9 & .9 \\
\hline & $\mathrm{D}$ & 14 & 12.4 & 13.3 \\
\hline \multirow{4}{*}{$\begin{array}{l}\text { You feel comfortable in using audio-visual aids, } \\
\text { particularly computer assisted electronic equipment. }\end{array}$} & $\mathrm{N}$ & 12 & 10.6 & 23.9 \\
\hline & A & 47 & 41.6 & 65.5 \\
\hline & SA & 39 & 34.5 & 100.0 \\
\hline & Total & 113 & 100.0 & \\
\hline
\end{tabular}

The results of data analysis are shown in frequency Table 1 . The results show that $61 \%$ of beginning English teachers $(B E T S)$ have declared that managing a big class (containing 30 above students) was not a very big problem but $39 \%$ take it as a big problem for managing a classroom. Behavioral problem from students have been found faced by $53 \%$ of teachers which is considered as a problem and $47 \%$ of teachers found no behavioral problem on students' part. Further, $56.6 \%$ BETs agree on facing trouble due to unruly students but $43.4 \%$ have no problem in this perspective. Likewise, $59.2 \%$ teachers admit the impact of some students on their interaction with the class but $40.8 \%$ do not face this issue. For $46 \%$ of teachers, maintaining a class, being new teachers is difficult but $54 \%$ do not take it as a problem. It was discovered that $55.8 \%$ observed almost no response from students during lecture but $44.2 \%$ teachers found getting response from students. The data reveals that $39.8 \%$ BETs complain about not adopting new techniques by students rather $60.2 \%$ do not complain about it. For $59.3 \%$ teachers, different mother tongues on the part of students create hurdle for making better understandings but $40.7 \%$ teachers there is not difficulty in this perspective. Further, $54 \%$ teachers complain that students do not carry their syllabus books with them in the class but $46 \%$ teachers observed students carrying books. Lack of completion of homework has been found by $70.8 \%$ of teachers but 29.2 have found students always completing their homework. Another indicator shows that $81.4 \%$ teachers agree that variation in students' mental capabilities makes it quite challenging to motivate all of them with the same techniques but $18.6 \%$ do not face this problem. Lack of audio-visual aids and its bad effects has been admitted by $76.1 \%$ of teachers but $23.9 \%$ do not have any concern with it.

The results in the Table 2 present the results of all the items which collectively form the composite variable of classroom management. The descriptive statistics present the number of cases or subjects $(N)$ of both; missing and valid separately, average or Mean for every single item, the Median (or middle) for all the items, Mode (or the frequently occurring) for all the items, Std. Deviation (standard deviation), and Skewness statistic and the Std. Error of the skewness, Minimum (smallest) and Maximum (largest) scores, and Percentile (in quartile fashion). The last row of the results demonstrates that the Valid $N$ is 113, which is the total amount of the respondents in this file of data. Only those persons were included in the $N$ who left no missing data against any requested variable in the output. To analyze the data file of the study the series mean was placed instead of missing values for showing permanent zero e.g., no participant with missing data. All the items (Modes, Means, Medians) in the Table 2 seem reasonable or according to the standards required by the normality. The evaluation of the data shows that fulfilment of the expectations (the information given in the codebook and the understandings made by the researchers about the variable) about the means were within the ranges. Appropriate range of Minimum and Maximum for all the variables were found normal. Consequently, no error was found in the data. 
Table 2. Data description: Univariate analysis of classroom management

\begin{tabular}{|c|c|c|c|c|c|c|c|c|c|c|c|c|c|}
\hline & & 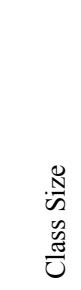 & 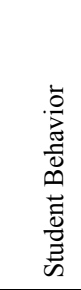 & 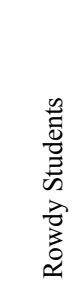 & 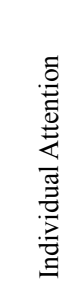 & 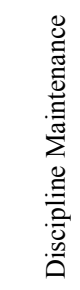 & 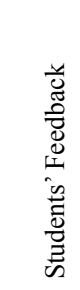 & 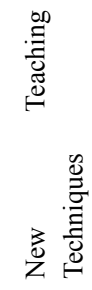 & 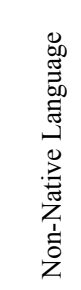 & 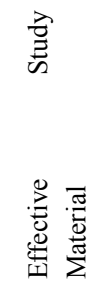 & 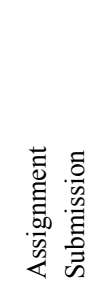 & 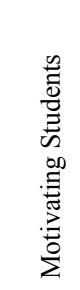 & 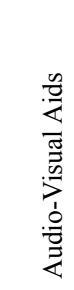 \\
\hline \multirow[t]{2}{*}{$\mathrm{N}$} & Valid & 113 & 113 & 113 & 113 & 113 & 113 & 113 & 113 & 113 & 113 & 113 & 113 \\
\hline & Missing & 0 & 0 & 0 & 0 & 0 & 0 & 0 & 0 & 0 & 0 & 0 & 0 \\
\hline \multicolumn{2}{|l|}{ Mean } & 3.035 & 3.318 & 3.539 & 3.469 & 3.115 & 3.477 & 2.929 & 3.486 & 3.300 & 3.769 & 3.902 & 3.964 \\
\hline \multicolumn{2}{|c|}{ Std. Error of Mean } & .1151 & .1007 & .1096 & .0924 & .1143 & .0982 & .1217 & .1103 & .1035 & .0957 & .0879 & .0956 \\
\hline \multicolumn{2}{|c|}{ Median } & 3.018 & 3.405 & 3.646 & 3.576 & 3.200 & 3.564 & 2.800 & 3.632 & 3.422 & 3.901 & 4.043 & 4.139 \\
\hline \multicolumn{2}{|l|}{ Mode } & 2.00 & 4.00 & 4.00 & 4.00 & 4.00 & 4.00 & 2.00 & 4.00 & 4.00 & 4.00 & 4.00 & 4.00 \\
\hline \multicolumn{2}{|c|}{ Std. Deviation } & 1.224 & 1.071 & 1.165 & .9826 & 1.215 & 1.044 & 1.293 & 1.173 & 1.101 & 1.017 & .9350 & 1.017 \\
\hline \multicolumn{2}{|c|}{ Variance } & 1.499 & 1.148 & 1.358 & .966 & 1.478 & 1.091 & 1.674 & 1.377 & 1.212 & 1.036 & .874 & 1.034 \\
\hline \multicolumn{2}{|l|}{ Skewness } & .021 & -.314 & -.512 & -.832 & -.194 & -.586 & .209 & -.626 & -.461 & -.815 & -1.33 & -.861 \\
\hline \multicolumn{2}{|c|}{ Std. Error Skewness } & .227 & .227 & .227 & .227 & .227 & .227 & .227 & .227 & .227 & .227 & .227 & .227 \\
\hline \multicolumn{2}{|c|}{ Range } & 4.00 & 4.00 & 4.00 & 4.00 & 4.00 & 4.00 & 4.00 & 4.00 & 4.00 & 4.00 & 4.00 & 4.00 \\
\hline \multicolumn{2}{|l|}{ Minimum } & 1.00 & 1.00 & 1.00 & 1.00 & 1.00 & 1.00 & 1.00 & 1.00 & 1.00 & 1.00 & 1.00 & 1.00 \\
\hline \multicolumn{2}{|l|}{ Maximum } & 5.00 & 5.00 & 5.00 & 5.00 & 5.00 & 5.00 & 5.00 & 5.00 & 5.00 & 5.00 & 5.00 & 5.00 \\
\hline \multirow[t]{3}{*}{ Percentiles } & 25 & 2.02 & 2.418 & 2.654 & 2.812 & 2.091 & 2.715 & 1.776 & 2.635 & 2.411 & 3.105 & 3.318 & 3.245 \\
\hline & 50 & 3.01 & 3.405 & 3.646 & 3.576 & 3.200 & 3.564 & 2.800 & 3.632 & 3.422 & 3.901 & 4.043 & 4.139 \\
\hline & 75 & 4.05 & 4.25 & 4.52 & 4.30 & 4.16 & 4.35 & 4.10 & 4.47 & 4.25 & 4.61 & 4.65 & 4.79 \\
\hline
\end{tabular}

\subsection{Interviews}

The qualitative data obtained through unstructured interviews was processed following the conventional categorization of the content. For this purpose, the models of Miles \& Huberman (1994) and Creswell (2003) methods were applied: Categorization: color coding of initial categories developed from the theoretical framework; identification of further categories; Recognition of relationships between variables and across the data sets; Interpretation of patterns and relationships; Identification of underlying themes conveyed.

Overall, the analysis of interviews confirmed the results obtained and interpreted from questionnaires. This was further confirmed through interviews that mostly teachers reflected self-efficacy. Seventeen out of twenty interview participants indicated their confidence in self-efficacy in the task mastery of classroom management skill. Three, however were of the opinion that they felt negative about their professionalization and it emerged as a great problem for them to maintain discipline in the classroom and thus they, being beginning teachers, lost their confidence sometimes. A little difference observed among the beginning English teachers was of varied opinions about task mastery of teaching skill of beginning teachers. It was observed that about $85 \%$ of the beginning teachers considered their teaching skill effective and expressed their success in employing appropriate teaching methodologies, scheduling syllabus and classroom activities, and managing classroom discipline, though a little difficult one. Whereas the few were of the opinion that beginning teachers were not so good in their teaching practices in classroom. The challenging areas of beginning teachers they pointed out were of lack of individual concentration on the pupils, less students' interests in classrooms, loose control on students, and unawareness of the new and appropriate teaching methodologies. Furthermore, the some BETs pointed out that teachers also lacked competence and mastery on the subject matter. However, most of the interviewees were satisfied with teaching methodologies being used by beginning teachers. The biggest problem pointed out was of classroom discipline as it was emphasized by five beginning teachers that they lost their confidence in the classrooms and remained unable to manage the classes as they wished.

\section{Discussion}

The results were in accordance with the objectives of the study to identify the challenges and problems beginning English teachers face during their early service while teaching in a school organization.

\subsection{Findings}

The basic focus of the study was to describe the issues of a classroom which become barriers and affect the performance of beginning English teachers. Thus, findings in relations with the objectives of the study have been 
discussed as follows:

- The collected data indicates that more number of students than standard number in one classroom affects the performance of teachers as well as of students.

- Majority of teachers face behavioral problem from students which has impact on beginning English teachers in managing classroom.

- Beginning English teachers also complain about unruly students who become cause of losing the discipline of classroom.

- Majority of the teachers also declare significant impact of some students' interaction when they try to interact with the other students of the class.

- Other than that, they also feel it difficult to maintain discipline of class that can be due to the hesitation or other factors of classroom.

- Another factor of disappointment for newly appointed teacher is lack of response from students when he/she is delivering lecture to a class and majority of teachers have been a victim of this problem.

- It has also been found disturbing for beginning English teachers that students were not ready to accept new ideas and a variety of techniques through which they try to expedite the teaching and learning processes.

- Though teachers try their best to teach children in a perfect way but variety of native languages on the part of students make it difficult for them to make better understandings for students.

- Majority of teachers also complain about students not carrying their syllabus books with them and incompletion of homework assigned to the students has always been a problem for majority of teachers.

- Motivating all the students with same technique has been found not much successful because of variation in mental capabilities of the students.

- Less utilization of electronic audiovisual aids also emerge as a challenge for beginning English teachers.

The findings were based on analysis of the data collected through questionnaires as well as the data collected through semi-structured interviews.

\subsection{Recommendations}

There are different suggestions submitted by the researchers which can be helpful in making classroom management efficient and effective: (1) A limited and specified number of students in one class makes it workable for a teacher to perform well and communicate to every student; (2) Different teaching methods and techniques such as student teacher interaction, peer work, group talk should be applied to improve students' classroom participation; (3) The teachers should appreciate students' achievements to promote a positive encouraging classroom environment; (4) The fundamental need of this age for a classroom in the form of technology based audio-visual aids must be provided in classrooms to enhance the performance of teachers, as well as students. Further, the studies may be conducted to find the better solution to address the weak areas in classroom management of beginning English teachers in particular context of Pakistani academic environment.

\subsection{Conclusion}

The detailed analyses and interpretations in findings represent the results which declare that beginning English teachers face a number of challenges in socialization content related to classroom management. The study has been successful in achieving its objectives and the answers of the research questions by describing the existence and degree of the classroom management challenges for beginning English teachers. These challenges have been described clearly through this study and will be help in understanding the cause of low performance of beginning English teachers. The challenges which have been found in this research study include the issues related to the excessive number of students, variation in their dialects/languages, their mental approaches, unexpected behaviors, lack of interest in the completion of homework, failure in brining books with them and lack of audio-visual aids. A number of things common in most of the participants were switching from one institution to the next, contract based job, teaching further subjects other than English in private sector. Shortly, in the early period of their career, beginning English teachers face so many organizational challenges struggling to adjust themselves there. The study has contributed to the body of the existing knowledge by pointing out the core issues in the most important area of socialization of beginning English teachers at school level which affects the performance of not only teachers but also of students and ultimately impacts the education system. 


\section{References}

Akhtar, R. N., \& Kausar, G. (2011). Pakistani students' and teachers' beliefs about English language learning at school level: An analytical study. Journal of Education and Practice, 2(5), 17-29. Retrieved from www.iiste.org

Baumrind, D. (1980). New directions in socialization research. American Psychologist, 35, $639-652$. http://dx.doi.org/10.1037/0003-066X.35.7.639

Blase, J. (1986). Socialization as humanization: One side of becoming a teacher. Sociology of Education, 59, 100-113. https://doi.org/10.2307/2112435

Cohen, L., Manion, L., \& Morrison, K. (2007). Research methods in education (6th ed.). London: Routledge.

Coleman, H. (Ed.). (1989). Lancaster-Leeds language learning in large classes. Research Reports no. 1-12. Leeds, England: University of Leeds.

Connell, R. W. (1985). Teachers'work. Sydney, Australia: Allen and Unwin.

Creswell, J. W. (1994). Research design: Qualitative \& quantitative approaches. Journal of Marketing Research, $33,252$.

Creswell, J. W. (2003). Qualitative, quantitative, and mixed methods approaches (2nd ed.). Thousand Oaks, CA: Sage.

Crystal, D. (1997). English as a Global Language. Cambridge: Cambridge University Press.

Denscombe, M. (1982). The hidden pedagogy and its implications for teacher training: An ecological analysis. British Journal of Sociology of Education, 3, 249-265. https://doi.org/10.1080/0142569820030303

Denzin, N. K., \& Lincoln, Y. S. (2000). Handbook of qualitative research. Thousand Oaks: Sage Publications.

Doyle, W. (1977). Learning the classroom environment: An ecological analysis. Journal of Teacher Education, 28, 51-55. https://doi.org/10.1177/002248717702800616

Doyle, W. (1979). Classroom effects. Theory into Practice, 18, $138-144$. https://doi.org/10.1080/00405847909542823

Hudson, P. (2012). How can schools support beginning teachers? A call for timely induction and mentoring for effective teaching. Australian Journal of Teacher Education, 37(7), 70-84. https://doi.org/10.14221/ajte.2012v37n7.1

Ingersoll, R., \& Strong, M. (2011). The impact of induction and mentoring programs for beginning teachers: A critical review of the research. University of Pennsylvania Scholarly Commons GSE Publications Graduate School of Education. https://doi.org/10.3102/0034654311403323

Jumani, N. B. (2007). Study on the competencies of the teachers trained through distance education in Pakistan. Unpublished post-doctoral research, Deakin University Australia.

Larson, S. (1986). Learning from experience: Teachers' conceptions of changes in their professional practice. Journal of Curriculum Studies, 19(1), 35-43. https://doi.org/10.1080/0022027870190104

Marzano, R. J., Marzano, J. S., \& Pickering, D. (2003). Classroom management that works: Research-based strategies for every teacher. Alexandria, VA: Association for Supervision and Curriculum Development.

Miles, M., \& Huberman, M. (1994). Qualitative data analysis (2nd ed.). Beverley Hills, CA: Sage.

Pollard, A. (1982). A model of classroom coping strategies. British Journal of Sociology of Education, 3, 19-37. https://doi.org/10.1080/0142569820030102

Rees, R. B. (2015). Beginning teachers' perceptions of their novice year of teaching. All graduate theses and dissertations graduate studies. DigitalCommons@USU: Utah State University.

Riseborough, G. (1988). Pupils, recipe knowledge, curriculum, and the cultural production of class, ethnicity, and patriarchy: A critique of one teacher's practices. British Journal of Sociology of Education, 9(1), 39-54. https://doi.org/10.1080/0142569880090103

Robson, C. (2002). Real world research (2nd ed.). Oxford: Blackwell.

Sarwar, Z. (2001). Adapting individualization techniques for large classes. In D. Hall \& A. Hewings (Eds.), Innovation in English language teaching: A reader (pp. 127-136). London: Routledge.

Sarwar, Z. (2001). Innovations in large classes in Pakistan. TESOL Quarterly, 35(3), $497-500$. 
https://doi.org/10.2307/3588033

Saunders, M., Lewis, P., \& Thornhill, A. (2007). Research methods for business students (4th ed.). Harlow: Pearson Education.

Tahir, A., \& Qadir, S. A. (2012). Challenges of classroom management to effective teacher socialization: A study of beginning English teachers. Pakistan Journal of Social Sciences, 32(1), 21-37.

\section{Copyrights}

Copyright for this article is retained by the author(s), with first publication rights granted to the journal.

This is an open-access article distributed under the terms and conditions of the Creative Commons Attribution license (http://creativecommons.org/licenses/by/4.0/). 